\title{
Peningkatan Hasil Belajar Siswa Pada Pelajaran PKn Yang Mencerminkan Perilaku Harga Diri Melalui Metode Bermain Peran
}

\author{
Fitria Kumala Sari \\ Sekolah Dasar 25 JTT, Padang \\ * e-mail: fitria.akbar86@gmail.com
}

\begin{abstract}
This research begins with the discovery of facts that are less satisfactory in learning PKN, namely still low student learning in SDN 25 JTT. In this case the learning process has not fully involved students, as well as the lack of use of media in the process of learning in the classroom that causes students less active and submitted material is not well received by students. to overcome these problems, then used the role playing method in learning PKN with material behavior that reflects self-esteem for students class III SDN 25 JTT Padang Timur.
\end{abstract}

Keywords: Fact, discovery; role playing; elementary school.

CC Licensees may copy, distribute, display and perform the work an make derivative and remixes based on it only if they
give the author or licensor the credits (attributtion) in the manner specified by these. Licensees may copy, distribute,
display, and perform the work and make derivative works and remixes based on it only for non-commercial purposes

\section{PENDAHULUAN}

Pendidikan dasar di Sekolah Dasar (SD) merupakan jenjang pendidikan yang sangat strategis karna merupakan pondasi untuk melanjutkan ke jenjang berikutnya. Oleh karena itu guru memegang peran yang sangat penting dan strategis dalam mewujudkan keberhasilan proses pembelajaran di SD.

Penopang dari tumbuh dan berkembangnya kehidupan berbangsa dan bernegara adalah melalui peningkatan tingkat kecerdasan warga negara (Civic Intlegensi), mengembangkan dimensi spiritual dan tanggung jawab warga negara (Civic Responsibility) dan parsitipasi warga negara dalam memajukan bangsanya (Civic participation).

Guru mempersiapkan generasi penerus bangsa seperti yang diinginkan diatas peran pendidikan dini sangat vital, karena dengan pendidikan sedini mungkin akan penanaman sikap berbangsa dan bernegara yang baik akan menjadi pondasi utama dari perilaku generasi dimasa yang akan datang.

Ditinjau dari segi keberhasilan pembelajarannya, pembelajaran mata pelajaran Pendidikan Kewarganegaraan diharapkan mampu membekali siswa dalam pengetahuan dan ketrampilan intelektual yang memadai serta pengalaman praktis agar memiliki kompetensi serta efektifitas dalam berpartisipasi. Ada dua hal yang perlu mendapat perhatian guru dalam mempersiapkan pembelajaran PKn yakni: Bekal pengetahuan materi pembelajaran dan metode atau pendekatan pembelajaran.

Pembelajaran mata pelajaran Pendidikan Kewarganegaraan dengan paradigma yang baru bertumpu pada kemampuan dasar kewarganegaraan (Civic Competence) untuk semua jenjang, sering kali guru dihadapkan pada kesulitan akan media dan model pembelajaran yang diperlukan dalam proses pembelajaran. Hal ini mengingat pelajaran PKn sangat lekat dengan pengembangan sikap dan perilaku siswa. Atau dengan kata lain muara dari pembelajaran PKn pada sekolah dasar bermuara pada aspek aktif siswa. 
Inilah yang menjadi tantangan guru, agar mampu menghadirkan proses pembelajaran mata pelajaran PKn yang menyenangkan dan mampu menarik perhatian bagi siswa dalam belajar.

Dalam kegiatan pembelajaran mata pelajaran PKn kelas III semester II dengan Kompetensi Dasar : Memberi contoh bentuk harga diri seperti menghargai diri sendiri, mengakui kelebihan dan kekurangan diri sendri dan lain-lain yang peneliti lakukan ternyata mengalami kesulitan.

Dari hasil pembelajaran yang dilakukan peneliti, ternyata cara dan kegiatan dalam pembelajaran yang dilakukan untuk mata pelajaran Pendidikan Kewarganegaraan di kelas III dengan Kompetensi Dasar Memberi contoh bentuk harga diri seperti menghargai diri sendiri, mengakui kelebihan dan kekurangan diri sendri dan lain-lain menggunakan strategi pembelajaran ceramah dan tanya jawab masih kurang memenuhi sasaran.

Dengan melihat dan mengamati hasil belajar siswa yang menunjukkan kekurang berhasilan dalam mengajar, peneliti mencoba untuk bertanya, meminta saran dan masukan dari teman sejawat dan bimbingan Ibu dosen pembimbing untuk mengidentifikasi kekurangan dalam pembelajaran yang peneliti lakukan.

Setelah melakukan identifikasi masalah dari proses pembelajaran yang dilakukan, akhirnya ditemukan beberapa hal yang dianggap sebagai penyebab kekurang berhasilan peneliti dalam mengajar, hal - hal tersebut adalah :

a. Kegiatan pembelajaran yang dilakukan peneliti dalam menyampaikan materi yang terlalu cepat, khususnya dalam jabaran materi tentang harga diri, sehingga materi ajar yang disampaikan belum bisa di pahami oleh siswa.

b. Metode pembelajaran yang masih kurang menarik perhatian siswa, khususnya masih dominannya metode penyampaian informasih ceramah. Serta media pembelajaran masih kurang diberikan kepada siswa, karena dalam proses pembelajaran ini guru hanya menggunakan media gambar yang ada di dalam buku teks pelajaran.

Dengan telah ditemukannya identifikasi masalah dalam pembelajaran awal, peneliti dengan bantuan teman sejawat dan bimbingan dosen pembimbing menganalisa kegiatan pembelajaran yang telah dilakukan, yang akan menjadi dasar dari kegiatan pembelajaran berikutnya.

Hasil temuan peneliti adalah sebagai berikut :

a. Penyampaian materi yang terlalu cepat sebagai akibat dari kepercayaan diri yang berlebihan dari peneliti saat proses penyampaian materi. Hal ini disebabkan peneliti merasa enjoy dan menganggap materi mudah diterima siswa.

Metode yang digunakan guru dirasa masih kurang bisa membawa suasana pembelajaran yang membangkitkan keaktifan siswa, sehingga dari analisis yang dilakukan peneliti untuk metode pembelajaran perlu ditambah agar bisa menarik minat belajar siswa.

Pengertian Pembelajaran PKn Menurut Asep Jihad dan Haris (2008:11), "Pembelajaran merupakan proses komunikasi antara peserta didik dengan pendidik serta antara peserta didik dalam rangka perubahan sikap." Kemudian dalam Asep Jihad dan Haris (2008:12) menyatakan,'Pembelajaran adalah suatu proses yang mengandung serangkaian perbuatan guru dan siswa atas dasar hubungan timbal balik yang berlangsung dalam situasi edukatif untuk mencapai tujuan tertentu."

Fungsi PKn Selanjutnya Menurut Nursid Sumaatmadja (2007: 1.10), Fungsi PKn sebagai pendidikan, yaitu membekali anak didik dengan pengetahuan sosial yang berguna, keterampilan sosial dan intelektual, dalam membina perhatian serta kepedulian sosialnya sebagai SDM Indonesia yang bertanggung jawab merealisasikan tujuan Nasional. Dengan pengetahuan sosial yang berguna, keterampilan sosial dan intelektual, dalam membina perhatian serta kepedulian sosialnya, dapat diharapkan terbinanya SDM Indonesia yang akan datang yang berpengetahuan, terampil, cendekia, dan mempunyai tanggung jawab sosial yang tinggi yang mampu merealisasikan tujuan Nasional menciptakan masyarakat adil dan makmur berdasarkan Pancasila serta Undang-Undang Dasar 1945.

Tujuan Pembelajaran PKn di SD menurut Zainul Ittihad Amin (2008:1.32), penguasaan kopetensi yang diharapkan bagi siswa setelah mempelajari pembelajaran PKn agar mampu: (a) Mempunyai kemampuan berpikir, bersikap Nasional dan dinamis. (b) Mempunyai wawasan 
kesadaran berbangsa dan bernegara untuk membela Negara yang dilandasi oleh rasa cinta tanah air. (c) Mempunyai wawasan kebangsaan, kesadaran berbangsa dan bernegara demi ketahanan Nasional untuk kelangsungan hidup bangsa dan Negara. (d) Mempunyai pola pikir, pola sikap yang koperhensif-integral dalam memecahkan masalah dan implementasi pembangunan nasional pada seluruh aspek kehidupan nasional.

Penelitian perbaikan pembelajaran ini diharapkan dapat bermanfaat: Bagi siswa a. Meningkatkan aktifitas belajar siswa dalam kelas, b. Meningkatkan pemahaman siswa tentang harga diri dengan cara bermain pera, c. Meningkatkan hasil belajar siswa SDN 25 Jati Tanah Tinggi Kecamatan Padang Timur. Sedangkan bagi Guru sebagai masukan bagi guru kelas III dalam pembelajaran PKn dalam penggunaan metode bermain peran (role play) dapat meningkatkan motivasi serta keaktifan siswa dalam memahami materi tentang harga diri. Serta suatu cara untuk mengoptimalkan peran siswa dalam kegiatan belajar mengajar khusus mengukur waktu dengan menggunakan metode bermain peran (role play).

Dalam proses pertumbuhan dan proses kehidupan kita, ternyata tidak mudah dalam membentuk sikap diri yang positif. Karena kita mungkin mempunyai pandangan yang tidak menyenangkan terhadap diri kita sendiri karena pengaruh komentar teman-teman, ortu, saudara atau orang lain. Bisa juga karena kita merasa gagal, tidak dapat berbuat apa-apa, merasa tidak dapat bertanggung jawab terhadap sesuatu yang ditugaskan, atau tidak bisa berkata jujur dan sebagainya.

Harga diri ini sebenarnya tidak hanya menjadi masalah kita, tapi hampir melanda semua orang di semua tingkatan umur. Harga diri pada tingkat apa pun merupakan pengalaman paling pribadi yang berada dalam inti kehidupan kita. Harga diri adalah apa yang kita pikirkan dan rasakan tentang diri kita sendiri, bukan apa yang dipikirkan dan dirasakan oleh orang lain tentang siapa kita sebenarnya. Tak seorang pun yang dapat mengendalikan kita dan memercayai kepercayaan dan kecintaan kita terhadap diri sendiri.

Banyak orang yang beranggapan bahwa harga dirinya akan naik jika ia dapat mengekspresikan kemarahannya. Menurutnya, dengan berani marah kepada siapa saja maka orang-orang akan menilainya sebagai seseorang yang keras sehingga setiap orang akan takut dan takluk kepadanya.

Harga diri merupakan penilaian dan penghargaan seseorang terhadap dirinya sendiri. Penilaian orang lain dapat memengaruhi bagaimana seseorang bertingkah laku dalam kehidupan sehari-hari. Tapi yang terutama adalah penilaian terhadap diri sendiri.

Harga diri yang sesungguhnya adalah merupakan harga diri atas kemuliaan karakter dari kita sendiri kita, yang meliputi keadilan, ibadah, kesetiaan, kasih, kesabaran, dan kelembutan. Kita dituntut untuk memiliki hal-hal tersebut agar bisa memiliki harga diri yang tinggi yang sesungguhnya. Semuanya itu dapat kita wujudkan melalui pembelajaran setiap hari. Hari-hari yang kita jalani, seharusnya dapat kita jadikan kesempatan untuk mengikis karakter buruk dalam diri kita dan mengembangkan kebiasaan yang baik untuk mewujudkan harga diri yang sesungguhnya. Dengan inilah kita bisa menjadi orang yang benar-benar berharga.

Seorang yang memiliki harga diri akan lebih bersemangat, lebih mandiri, lebih mampu dan berdaya, sanggup menerima tantangan, lebih percaya diri, tidak mudah menyerah dan putus asa, mudah memikul tanggung jawab, mampu menghadapi kehidupan dengan lebih baik, dan merasa sejajar dengan orang lain.

Harga diri tidak dibawa sejak lahir, tetapi memerlukan proses yang dibentuk sejak lahir karena itu dipengaruhi oleh banyak hal sepanjang hidup kita, misalnya, pengasuhan orangtua atau keluarga, pendidikan yang diterima (baik di sekolah ataupun di luar sekolah), pengalamanpengalaman yang berarti, prestasi-prestasi yang diraih, orang-orang terdekat (baik saudara maupun orang lain), budaya, lingkungan sosial dan masyarakat.

Yang menyedihkan banyak orang mencari kepercayaan dan penghormatan diri ke segala penjuru dunia selain dirinya sendiri sehingga mereka gagal dalam pencarian ini. Kita akan melihat bahwa harga diri yang positif paling baik dipahami sebagai salah satu bentuk dari pencapaian spiritual atau memahami harga diri sebagai suatu kondisi kesadaran. Sehingga kita 
akan berhenti mengatakan, "Kalau aku memiliki teman yang lebih keren, kalau aku punya pacar lagi, kalau aku mendapatkan penghargaan lagi, kalau aku mendapatkan mobil yang bagus, maka aku akan sungguh-sungguh berbahagia dengan diriku sendiri". Kita akan menyadari bahwa pernyataan itu sangat tidak rasional, maka "semakin banyak" keinginan yang akan mengusik hati kita.

Jika kita mendalami benar hakikat sejati harga diri, maka kita akan tahu bahwa harga diri tidak bersifat kompetitif (persaingan) dan komparatif (perbandingan). Harga diri yang sejati tidak diungkapkan melalui pemujaan diri dengan mengorbankan orang lain atau dengan mengagungkan seseorang jauh lebih unggul dari orang lain atau menyengsarakan orang lain untuk membahagiakan seseorang. Arogansi (kesombongan) dan terlalu mengagungkan kemampuan hanyalah menggambarkan betapa rapuhnya harga diri kita dan bukannya mencerminkan kokohnya harga diri kita.

Sebuah harga diri yang tepat dapat menjadi semacam magnit yang menyedot semua elemen kesuksesan. Harga diri itu semacam magma yang membangkitkan kembali kekuatan dahsyat dalam diri kita. Hanya dengan harga diri yang tepat kita bisa menatap masa depan dengan penuh kebanggaan. kita layak memperoleh kesuksesan.. mari tempatkan harga diri dalam konteks yang tepat

Stuart dan Sundeen (1991), mengatakan bahwa harga diri (self esteem) adalah penilaian individu terhadap hasil yang dicapai dengan menganalisa seberapa jauh perilaku memenuhi ideal dirinya. Dapat diartikan bahwa harga diri menggambarkan sejauhmana individu tersebut menilai dirinya sebagai orang yang memeiliki kemampuan, keberartian, berharga, dan kompeten

Menurut pendapat beberapa ahli tersebut, maka penulis dapat menyimpulkan bahwa harga diri (self esteem) adalah penilaian individu terhadap kehormatan diri, melalui sikap terhadap dirinya sendiri yang sifatnya implisit dan tidak diverbalisasikan dan menggambarkan sejauh mana individu tersebut menilai dirinya sebagai orang yang memeiliki kemampuan, keberartian, berharga, dan kompeten.

\section{METODE PENELITIAN}

Hasil identifikasi permasalahan yang telah didiskusikan bersama supervisor dan teman sejawat menjadi bahan kajian bagi penulis untuk melakukan refleksi diri, pada akhirnya dapat disimpulkan sebagai rumusan masalah yang harus dicari alternative pemecahannya dari tindakan/ rencana yang dapat dilakukan untuk melaksanakan perbaikan. Adapun rumusan masalahnya adalah : Peningkatan hasil belajar siswa pada pelajaran PKn yang mencerminkan perilaku harga diri melalui metode bermain peran di kelas III Semester II SDN 25 Jati Tanah Tinggi Kecamatan Padang Timur.

Secara oprasional dari rumusan maslaah tersebut dijabarkan melalui penelitia yaitu: apakah dengan menggunakan metode bermain peran dapat meningkatkan hasil belajar siswa pada pelajaran PKn yang mencerminkan perilaku harga diri.

Menurut Pusat Bahasa Indonesia Depdiknas (2007) "Bermain" artinya bersenang-senang dengan melakukan sesuatu, sedangkan "Peran" artinya memerankan atau melakukan dengan aktif. Jadi metode Bermain Peran adalah teknik pembelajaran dalam menyampaikan pesan untuk mencapai tujuan pembelajaran denan memerankan atau melakukan peran berpura-pura secara aktif dengan perasaan gembira.

Metode dibedakan dari pendekatan. Pendekatan lebih menekankan pada strategi dalam perencanaan sedangkan metode lebih menekankan pada teknik pelaksanaannya. Satu pendekatan yang direncanakan untuk satu pembelajaran mungkin dalam pelaksanaan proses tersebut digunakan beberapa metode.

Sebagai contoh dalam pembelajaran PKn yang mencerminkan perilaku harga diri. Pendekatan yang digunakan dalam pembelajaran tersebut dapat dipilih dari beberapa pendekatan yang sesuai, antara lain pendekatan dengan metode bermain peran. Ketika proses pemelajaran tentang mencerminkan harga diri dilaksanakan dengan pendekatan bermain peran tersebut dapat digunakan beberapa metode, misalnya metode observasi, metode diskusi, dan metode ceramah. 
Berdasarkan hal tersebut dapat disimpulkan bahwa metode dan pendekatan dirancang untuk mencapai keberhasilan suatu tujuan pembelajaran.

Salah satu metode yang paling disukai oleh peserta didik adalah metode bermain peran. Pembelajaran dengan metode bermain peran adalah pembelajaran dengan cara seolah-olah berda dalam situasi untuk memperoleh suatu pemahaman tentang suatu konsep. Dalam metode ini siswa berkesempatan terlibat secara aktif sehingga akan lebih memahami konsep dan lebih lama mengingat tetapi memerluka waktu lama

\section{HASIL PENELITIAN DAN PEMBAHASAN}

\section{Hasil Penelitian}

Pelaksanakaan penelitian ini pada siswa kelas II SDN 25 Jati Tanah Tinggi Kecamatan Padang Timur, tentang pembelajaran perilaku yang mencerminkan harga diri semester II. Dalam pelaksanaan tindakan pembelajaran guru bertindak sebagai peneliti sedangkan teman sejawat bertindak sebagai pengamat atau observasi.

Dalam pembelajaran yang mencerminkan harga diri dengan menggunakan metode bermain peran dengan rentang waktu 3 minggu, didapatkan hasil penelitian pada Pra-siklus, siswa masih kurang mampu atau memahami pembelajaran PKn tentang perilaku yag mencerminkan harga diri maka perlu dilakukan pembelajaran ulang dalam siklus ke pertama.

Dalam siklus pertama, dapat diketahui bahwa pembelajaran dapat meningkatkan hasil belajar dan keaktifan siswa dalam belajar. Hal ini dapat dilihat dalam persentase ketuntasan siswa yakni 30,76\% meningkat menjadi 69,23\%. Akan tetapi hal ini belum menemukan titi sempurna, Maka dilanjutkan pada Siklus ke II. Dimana dalam siklu kedua didapatkan hasil perbaikan pembelajaran dapat meningkatkan keaktifan belajar siswa yang dapat dilihat dari persentase ketuntasan dari Pra-siklus 30,76\%, Siklus I 67,23\% meningkat pada siklus II yakni 100\%.

Melaksanakan pembelajaran dalam dua siklus ternyata meningkatkan hasil belajar siswa. Untuk memaksimalkan maka diperlukan penambahan tindakan kepada siswa seperti meberikan pengertian kepada siswa yang kurangaktif, dan dalam pelaksanakaan Siklu II berpedoman pada rencana pembelajar Siklus I

\section{PEMBAHASAN}

Menurut Gunawan, Wahyu. M (2009:8) menyatakan," Dunia bermain peran sangat penting bagi anak-anak. Permainan yang mengutamakan jiwa ksatria dan sportif sangat bermanfaat, demikian halnya dengan permainan yang dapat menjadikan anak-anak mampu bergaul dengan menempatkan diri di tengah komunitasnya, apalagi ternyata permainan-permainan tersebut dapat dilakukan bersama-sama di tempat dan waktu yang disepakati."

Kelebihan Metode Bermain Peran: (a) Membuat suasana pembelajaran menjadi lebih menarik. (b) Memacu kreatifitas siswa dalam mengembangkan pengetahuannya. (c) Mengasah kemampuan guru dalam menciptakan inovasi dalam pembelajaran. (d) Mengembangkan sikap kerjasama antar siswa. (e) Membuat interaksi antara guru dengan siswa menjadi lebih akrab.

Kelemahan Metode Bermain Peran. (a) Pada umumnya yang lebih aktif hanya yang bermain peran saja. (b) Guru merasa kesulitan dalam memanajemen kelas. (c) Sulit untuk menyesuaikan dengan lamanya waktu pembelajaranm.

Untuk mengatasi kelemahan di dalam bermain peran adalah: (1) Skenario harus dirancang dan disesuaikan dengan karakteristik siswa sekolah dasar. (2) Siswa harus dilibatkan langsung dalam bermain peran. (3) Guru memotivasi dan mengarahkan siswa agar menggunakan waktu seefesien mungkin.

Manfaat Bermain Peran Menurut Muliawan Jasa Ungguh (2008:19) manfaat main bagi tumbuh kembang anak dibedakan dalam lima karakter golongan yaitu : manfaat motorik, afektif, kognitif, spiritual dan keseimbangan: (1) Manfaat motorik adalah manfaat yang berhubungan 
dengan unsur-unsur kesehatan, keterampilan, ketangkasan, maupun kemampuan fisik tertentu. (2) Manfaat afektif adalah manfaat mainan yang berhubungan dengan naluri atau insting, perasaan, emosi, sifat, karakter, watak, maupun kepribadian seseorang. (3) Manfaat kognitif adalah manfaat mainan yang berhubungan dengan kemampuan imajinasi, pembentukan nalar, logika, maupun pengetahuan sistematis. (4) Manfaat spiritual adalah manfaat mainan yang hampir sama dengan afektif tetapi mengandung unsur-unsur kesucian, keluhuran budi pekerti dan nilai-nilai positif. Dengan kata lain, manfaat spiritual merupakan perpaduan nilai-nilai positif dari afektif dan kognitif. (5) Manfaat keseimbangan merupakan manfaat mainan ditentukan berdasarkan maksud dan tujuan dari pembuatan itu sendiri.

Menurut Anitah. Sri W (2007:1,2), Metode berarti cara. Apabila dikaitkan dengan pembelajaran, metode cara yang digunakan guru dalam membelajarkan siswa dan penghayatan dilakukan siswa dengan memerankan sebagai tokoh hidup atau benda mati. Permainan ini pada umumnya dilakukan lebih dari 1 orang, hal ini tergantung kepada apa yang diperankan.

Dari pendapat di atas maka dapat disimpulkan bahwa metode bermain peran merupakan salah satu metode yang dapat menyajikan bahan pelajaran dengan cara memainkan peran dan mendramatisasikan suatu situasi sosial yang mengandung suatu masalah dengan harapan agar peserta didik dapat memecahkan masalah yang dihadapi dalam hubungan sosial dengan orangorang di lingkungan keluarga, sekolah maupun di masyarakat.

Dalam permasalahan kegiatan perbaikan pembelajaran lebih dirumuskan pada penanaman konsep-konsep PKN sederhana dan mampu menggunakan metode bermain peran tentang bagaimanaberprilaku yang mencerminkan harga diri di lingkungan sekitar. Dalama hal ini ditemukan beberapa permasalahan mendasar yang menyebabkan rendahnya tingkat kemampuan, sehingga pada akhir pelaksanaan kegiatan, perbaikan pembelajaran siswa diharapkan sudah mengalami peningkatan perolehan nilai yang kurang dari batas KKM.

Adapun peningkatan pada akhirnya untuk mata pelajaran PKn sebagai berikut: a. peningkatan hasil belajar siswa kelas III SDN 25 Jati Tanah Tinggi pada mata pelajaran PKn semakin membaik, b. motovasi dan kemampuan siswa dalam menerima pembelajaran semakin terarah dan membaik, c. aktifitas dan kreatifitas siswa dalam mengikuti pelajaran PKn semakin meningkat

\section{SIMPULAN DAN SARAN}

Hasil penelitian menunjukkan bahwa model pembelajaran bermain peran dapat dilakukan pada siswa sekolah dasar khususnya di kelas III. Karna dengan adanya metode pembelajaran yang berfariasi yang optimal dapat memberikan rangsangan kreatifitas siswa sehingga suasana kelas konduktif, aktif dan menyenangkan

Dari kesimpulan di atas disarankan agar Guru dalam mengajarkan hendaknya melibatkan siswa secara aktif, agar siswa meras lebih di hargai di perhatikan sehingga akan meningkatnya perilaku yang baik. Serta memberikam kesempatan kepada siswa untuk melakukan pertanyaan dan motifasi dalam pelajaran. Didalam kegiatan pembelajaran hendaknya siswa di motifasi untuk mampu bermain peran dalam kehidupan sehari-hari sehingga siswa akan lebih mampu mengkonstrasikan pengalamannya ke dalam konsep pelajaran yang sedang di pelajaran, sehingga di dalam konsep pelajaran yang sedang di pelajari, sehingga dalam mengajar dapat berperan sebagai fasilitator dan motifator yang bisa memberikan dan menyediakan pengalaman belajar yang memungkinkan siswa untuk bertanggung jawab dalam melakukan proses pembelajaran.

\section{DAFTAR PUSTAKA}

Asep Jihad dan Abdul Haris (2009). Evaluasi Pembelajaran, Multi Press. Yogyakarta

Anitah. Sri W (2007). Strategi dan Teknologi Pembelajaran di SD. Universitas Terbuka. Jakarta 
Arif Sukadi Sadiman (1989). Beberapa aspek Pengembangan Sumber Belajar. Jakarta: PT. Mediatama Sarana Perkasa

Depdiknas (2007). Kamu Besar Bahasa Indonesia. Jakarta: Balai Pustaka

Gunawan, Wahyu M (2009). Bermain Itu Asyik. Elmatera Publishing Malang

Muliawan Jasa Ungguh (2009). Tipe Jitu memilih Mainan Edukasif. Diva Press. Jogjakarta

Nursid Sumaatmaja (2007). Teknologi Pembelajaran. SIC. Surabaya

Zainul Ittihad Amin (2008). Pembelajaran Pendidikan Kewarganegaraan. Universitas Terbuka. Jakarta 